\title{
KSIĘGA OZEASZA W SEPTUAGINCIE
}

Księga Ozeasza otwiera zbiór Dwunastu Proroków, zarówno w tradycji hebrajskiej (TM), jak i greckiej (LXX). ${ }^{1}$ Takie jej położenie w kanonie było odzwierciedleniem nie tylko chronologii powstania poszczególnych ksiąg (obok Księgi Amosa pozostaje ona jedną z najstarszych ksiąg prorockich, a nawet ksiąg Starego Testamentu), ani nie tylko jej długości (14 rozdziałów Księgi Ozeasza czyni z niej najdłuższą księgę zbioru proroków mniejszych), ale także szczególnej roli, jaką ta księga odgrywała w czasach biblijnych i pobiblijnych. Jej teologia wpłynęła bowiem na późniejsze tradycje, zarówno w łonie judaizmu i chrześcijaństwa, a wątki w niej podjęte stały się podstawą wielu wtórnych interpretacji. ${ }^{2}$

Omawiając tekst LXX, w przypadku Księgi Ozeasza najpierw należy rozważyć wątek ogólniejszy: czy w ogóle można omawiać tę księgę w LXX osobno od pozostałych Dwunastu Proroków, skoro w zasadzie są one w LXX traktowane razem (teologicznie

1 Jest tak we wszystkich rękopisach Dwunastu Proroków, zarówno w TH, jak i TG. Por. na ten temat choćby: E. B o n s, J. J o o s t e n, S. K e s s 1 e r, La Bible d'Alexandrie. Les Douze Prophètes. Oseé. Traduction du texte grec de la Septante, introduction et notes, La Bible d'Alexandrie XXIII/1, Paris 2002, s. 24; J.M. D i n e s, The Minor Prophets, w: J. K. A i t k e n (red.), The T\&T Clark Companion to the Septuagint, Bloomsbury T\&T Clark, London i in. 2015, s. 439-440.

2 Chodzi zwłaszcza o kontekst małżeński (Ozeasza i Gomer) na wyrażenie prawdy o relacji Boga z Jego ludem (na jego temat wraz z bibliografią zob. B. S $t \mathrm{r}$ z a $\nmid$ k o w s k a, Gomer-problematyczna żona czyli obraz Izraela $w$ historii zbawienia, w: A. K u b i ś, K. N a p o r a (red.), „Niewiastę dzielna kto znajdzie?” /Prz 31,10/. Rola kobiet w biblijnej historii zbawienia, Analecta Biblica Lublinensia 14, Wydawnictwo KUL, Lublin 2016, s. 223-244); ale i o całą późniejszą tradycję przedstawiania relacji Boga i Izraela (a w chrześcijaństwie - Boga i Kościoła) na wzór relacji małżeńskich (lub oblubieńczych): np. w Księdze Ezechiela, w Pieśni nad Pieśniami, w listach św. Pawła i tradycjach teologicznych pobiblijnych. 
i tekstualnie). W tym kontekście trzeba wspomnieć również o rękopisach LXXOz, jakie posiadamy, zwracając uwagę na stan tekstu greckiego tej księgi. Druga część artykułu dotyczyć będzie charakterystycznych cech przekładu i różnic obecnych w LXXOz względem TM. Od razu trzeba powiedzieć, że nie są one spektakularne, jak w przypadku Księgi Hioba, Jeremiasza czy Przysłów (gdzie tekst jest dużo krótszy lub dłuższy, a zmiany wyraziste) - tu są one bardziej zniuansowane, ukazujące pracę tłumacza nad tekstem hebrajskim, a także wskazujące na bogactwo i różnorodność starożytnych tradycji tekstualnych Księgi Ozeasza. Będzie chodziło o różnice gramatyczne, błędy w odczytaniu hebrajskich spółgłosek, rdzeni czy wokalizacji, ale też zmiany intencjonalne tłumacza, z których szczególnie interesujące są zwłaszcza te o charakterze ideologicznym (np. ukazujące stosunek tłumacza LXX do Egiptu, który jest niezwykle ważnym tematem w Księdze Ozeasza). Ostatnią kwestią będzie krótkie omówienie datacji greckiego przekładu omawianej księgi.

\section{LXXOz w kontekście zbioru Dwunastu Proroków. Rękopisy LXXOz}

Pierwszy problem, jaki nasuwa się w związku z grecką tradycją Księgi Ozeasza, to ten, że w zasadzie LXX traktuje Dwunastu Proroków zawsze razem. ${ }^{3} \mathrm{Na}$ to wskazuje porządek posiadanych przez

3 Ten złożony problem podejmowany był zarówno w odniesieniu do tekstu greckiego, jak i hebrajskiego. Podsumowanie tego tematu dla tekstu LXX zob. W.E. G 1 e n n y, Hosea. A Commentary Based on Hosea in Codex Vaicanus, Septuagint Commentary Series 10, Brill, Leiden-Boston 2013, s. 1 (oraz omówienie końca Księgi w komentarzu, s. 185); A. S c har t, Dodekapropheton. Das Zwölfprophetenbuch, w: M. K a r r e r, W. K r a u s i in. (red.), Septuaginta Deutsch. Erläuterungen und Kommentare zum gieschischen Alten Testament, t. II: Psalme bis Daniel, Stuttgart 2009, s. 2275-2286; G.E. H o w a r d, The Twelve Prophets. To the Reader, w: A. P i e t e r s m a, B.G. Wr i g h t (red.), A New English Translation of the Septuagint. And the Other Greek Translations Traditionally Included under that Title, New York-Oxford 2007, s. 777-781, zwł. s. 780-781; C.R. H a r r i s o n, The Unity of the Minor Prophets in the LXX: A Reexamination of the Question, Bulletin of the International Organization for Septuagint and Cognate Studies 
nas rękopisów, a także tradycja biblijna: zwłaszcza Księga Syracha, która w w. 49,10 (w greckiej tradycji) wspomina Dwunastu Proroków razem, a nie poszczególne księgi (chodzi o słynny tekst: $\kappa \alpha i ~ \tau \hat{\omega} \nu$

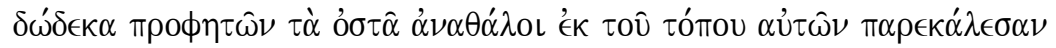

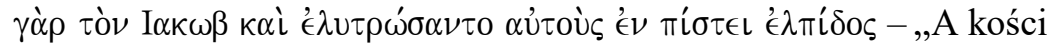
dwunastu proroków z miejsca ich ${ }^{4}$ niech wypuszczą pędy, pocieszyli bowiem Jakuba i wybawili go niezawodną nadzieją"). ${ }^{5}$ Podobnie

21/1988, s. 55-72 ; T. M o u r a o k a, In Defence of the Unity of the Septuagint Minor Prophets, Annual of the Japanese Biblical Institute 15/1989, s. 25-36. Zob. także dawniejsze opracowania: A. K a m i n k a, Studien zur Septuaginta an der Hand der zwölfkleinen Prophetenbücher, Monatsschrift für Geschichte und Wissenschaft des Judentums 72/1928, s. 49-60, 242-273; L. Tr e i t e 1, Wert und Bedeutung der Septuaginta zu den 12 kleinen Propheten, Monatsschrift für Geschichte und Wissenschaft des Judentums 73/1929, s. 232-234; J. Z i e g 1 e r, Studien zur Verwetung der Septuaginta im Zwölfprophetenbuch, Zeitschrift für die alttestamentliche Wissenschaft 60/1944, s. 107-131; P. K a h 1 e, Die Lederrolle mit dem griechischen Text der Kleinen Propheten und das Problem der LXX, Theologische Literaturzeitung 79/1954, s. 81-94; J. Z i e g 1 e r, Zur Dodekapropheton-LXX, Ephemerides Theologicae Lovanienses 38/1962, s. 904-906; C. D o g n i e z, Le Dieu des armées dans le Dodekapropheton, w: B.A. T a y 1 o r (red.), IX Congress of the International Organization for Septuagint and Cognate Studies, Cambridge 1995, Society of Biblical Literature Septuagint and Cognate Studies Series 45, Atlanta 1997, s. 19-36; t a ż, Fautes de traduction, ou bonnes traductions? w: B.A. T a y lor (red.), $X$ Congress of the International Organization for Septuagint and Cognate Studies, Oslo 1998, Society of Biblical Literature Septuagint and Cognate Studies Series 51, Atlanta 2001, s. 241-261; J. J o o s t e n, A Septuagintal Translation Technique in the Minor Prophets. A Septuagintal Translation Technique in the Minor Prophets. The Elimination of Verbal Repetitions, w: G. Martín e z F lor e n t i no (red.), Interpreting Translation, Bibliotheca Ephemeridum Theologicarum Lovaniensium 192, Leuven 2005, s. 217-223; M. A u s s e d a t, Le regroupement des livres prophétiques dans la Septante d'après le témoignage des chaînes exégétiques, w: M.K.H. P e t e r s (red.), XII Congress of the International Organization for Septuagint and Cognate Studies Leiden 2004, Society of Biblical Literature. Septuagint and Cognate Studies 54, Atlanta, Georgia 2006, s. 169-185.

4 BT mówi o, ,ich grobie”.

5 Por. W.E. G 1 e n n y, Hosea. A Commentary Based on Hosea in Codex Vaicanus, s. 1. 
traktował je razem Józef Flawiusz, w dziele Przeciw Apionowi 1,8, ${ }^{6}$ zaś Talmud Babiloński sugerował, by, przepisując rękopisy biblijne, pozostawiać 4 linie wolne między księgami kanonicznymi, ale tylko 3 w przypadku 12 ksiąg proroków mniejszych. ${ }^{7}$

Także w tradycji chrześcijańskiej traktowano je łącznie. Święty Hieronim w swoim komentarzu do Księgi Ozeasza (Commentaria in Osee, datowanym na lata 406-407 po $\mathrm{Chr}^{8}{ }^{8}$ ), interpretując sam początek księgi (Oz 1,1-2), wskazywał, że zdanie ,początek słowa Pana

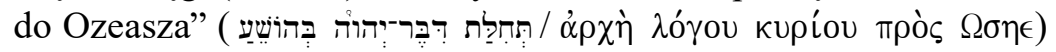
jest wprowadzeniem do całości Dwunastu Proroków i należałoby je rozumieć mniej więcej tak: „Na początku gdy Bóg przemawiał do proroków, zaczął od Ozeasza". ${ }^{9}$ Nowy Testament zawiera 33 cytaty z ksiąg proroków mniejszych (nazywanych po prostu zbiorczo Prorokami; obok 72 cytatów z Księgi Izajasza, 10 z Jeremiasza oraz 5 z Ezechiela). ${ }^{10}$

6 Tamże.

7 P.L. R e d d d it t, The Formation of the Book of the Twelve: A Review of Research, w: t e n ż e (red.), Thematic Threads in the Book of the Twelve, Walter de Gruyter, Berlin 2003, s. 1; por. także: W.E. G 1 e n n y, Hosea. A Commentary Based on Hosea in Codex Vaicanus, s. 1.

8 Łaciński tekst krytyczny tego komentarza zob. M. A d r i a e n, S. Hieronymi presbyteri Opera. Pars I: Opera exegetica 6. Commentarii in prophetas minores (Osee, Ioelem, Amos, Abdiam, Ionam, Michaean), CCL 76, Turnhout 1969; por. także: A. F e r r e i r o, T.C. O d e n, Ancient Christian Commentary on Scripture. Old Testament XIV. The Twelve Prophets, Wheaton 2003. Na temat datacji m.in. tego komentarza Hieronima do Oz zob. Św. Hieronim, Komentarz do Księgi Abdiasza (Commentarius in Abdiam, CPL 589), przekład, oprac. i wstęp Ł. K r z y s z c z u k, Vox Patrum 33/2013, t. 60, s. 557-601.

9 E. B o n s, J. J o o s t e n, S. K e s s l e r, La Bible d'Alexandrie. Les Douze Prophètes. Oseé, s. 24.

10 T. M o u r a o k a, Introduction aux Douze Prophètes, w: La Bible d'Alexandrie. Les Douze Prophètes. Oseé, s. 1-17; por. W.E. G 1 e n n y, Hosea. A Commentary Based on Hosea in Codex Vaicanus, s. 2; por. J.M. D i n e s, The Minor Prophets, w: J. K. A i t k e n (red.), The T\&T Clark Companion to the Septuagint, s. 451; A. P a s s o n i d e 1 l' A c q u a, L'edizione della versione greca-LXX-del libro di Osea, Rivista biblica 51(2003)1, s. 316. 
Na wspólne traktowanie Dwunastu Proroków wskazują także rękopisy. Zauważa to J. Ziegler, autor opracowania Księgi Dwunastu Proroków w serii z Göttingen, ${ }^{11}$ a także inni badacze tekstu LXX: ${ }^{12}$ m.in. H. St. J. Thackeray, który podjął ten temat jako pierwszy w 1920 r., orzekając jednoznacznie jedność greckiego przekładu Proroków Mniejszych, sugerując zarazem, że tłumaczenie to wyszło spod pióra jednego tłumacza ${ }^{13}$.

W.E. Glenny zwraca uwagę, że Kodeks Watykański (najstarszy rękopis zawierający pełen tekst Dwunastu Proroków ${ }^{14}$ ) ma na końcu każdej księgi proroków mniejszych numerację od 1 do 12 , zaznaczając kolejno poszczególne księgi zbioru (ale sugerując jednocześnie, że są one jednością). ${ }^{15}$ Pozostałe najstarsze greckie rękopisy (wyliczone skrupulatnie przez J. Zieglera w wydaniu krytycznym ${ }^{16}$ ) także traktują je jako całość: chodzi zwłaszcza o majuskuły, jak papirus W (z III w. po Chr., znajdujący się obecnie w Waszyngtonie, zawierający fragmenty ksiąg proroków mniejszych, dokładnie

11 J. Z i e g l e r (red.), Septuaginta. Vetus Testamentum Graecum. Auctoritate Academiae Scientiarum Gottingensis editum, t. XIII: Duodecim prophetae, Vanhoeck\& Ruprecht, Göttingen 1984.

12 Zob. przyp. 3.

13 Tezę tę opublikował w wydanej rok później książce: H. St. J. T h a c k e r a y, The Septuagint as Jewish Worship. A Study in Origins, Schweich Lectures (British Academy), London 1921; zob. G.E. H o w a r d, The Twelve Prophets. To the Reader, w: A. P i e t e r s m a, B.G. Wrig h t (red.), A New English Translation of the Septuagint, s. 780. H. St. J. T h a c k e r a y pisał wcześniej na temat proroków, por. t e n ż e, The Greek Translators of the Prophetical Books, Journal of Theological Studies 4/1903, s. 578-585.

14 Por. J.M. D i n e s, The Minor Prophets, w: J. K. A i t k e n (red.), The T\&T Clark Companion to the Septuagint, s. 438.

15 W.E. G 1 e n n y, Hosea. A Commentary Based on Hosea in Codex Vaicanus, s. 1 (oraz omówienie końca księgi w komentarzu, s. 185). Kodeks B można skonsultować także na niedawno utworzonej stronie internetowej ze zdigitalizowanymi rękopisami ze zbiorów Biblioteki Watykańskiej (Dwunastu Proroków od numeru karty 945; Księga Ozeasza to karty 945-954): http://digi.vatlib.it/view/MSS_Vat. gr.1209 (dostęp 1 I 2016).

16 J. Z i e g l e r (red.), Septuaginta. Vetus Testamentum Graecum, t. XIII: Duodecim prophetae, s. 7-119. 
fragmenty Księgi Ozeasza i początek Księgi Amosa i inne drobne fragmenty pozostałych ksiąg); ${ }^{17}$ czy Kodeks Synaicki (S) z IV w. po Chr. (,wybrakowany” jednak o tyle, że nie ma w nim zachowanej Ksiąg Ozeasza, Amosa czy Micheasza ${ }^{18}$ ) oraz Kodeks Venetus (V) z VIII w. po Chr. Te trzy (wraz z czwartym - wspomnianym wcześniej Kodeksem Watykańskim) często zgodne są ze sobą, w przeciwieństwie do kodeksów Aleksandryjskiego (A) z V w. po Chr. (zawierającego czasem harmonizacje, rozszerzenia ${ }^{19}$ ) i Q (z VI/ VII w., obecnie przechowywany w Rzymie w Bibliotece Watykańskiej, zawierający wszystkie księgi prorockie: 4 większych i 12 mniejszych proroków). ${ }^{20}$ Te ostatnie prezentują inną (aleksandryjską) wersję tekstu. Tekst antiocheński z kolei i recenzja Lucjana reprezentowana jest przez niektóre kodeksy minuskułowe i cytaty LXXOz u Ojców Kościoła i pisarzy wczesnochrześcijańskich: Jana Chryzostoma, Teodora z Mopsuestii czy Teodoreta z Cyru, ${ }^{21}$ a także przez wersję ormiańską, który to przekład został oparty na LXX i jest ważnym świadkiem greckiego tekstu księgi. ${ }^{22}$

Dla greckiej tradycji najstarszym świadectwem tekstualnym Dwunastu Proroków jest odnaleziony w 1953 r. w Nahal Hever na Pustyni Judzkiej (między Ein Gedi a Masadą) rękopis LXX, zawierający księgę proroków mniejszych razem (8HevXIIgr). ${ }^{23}$ Rękopis ten da-

17 Por. Offizielles Verzeichnis der Rahlfs-Sigeln. Herausgegeben vom Septuaginta-Unternehmen der Akademie der Wissenschaften zu Göttingen, Göttingen 2012, s. 1.

18 J.M. D i n e s, The Minor Prophets, w: J. K. A i t k e n (red.), The T\&T Clark Companion to the Septuagint, s. 438.

19 Tamże.

20 A. P a s s o n i d e ll' A c qu a, L'edizione della versione greca-LXX-del libro di Osea, s. 317.

${ }^{21}$ Tamże, s. 317-318. Na temat m.in. tych komentarzy patrystycznych zob. także: E. B o n s, J. J o o s t e n, S. K e s s 1 e r, La Bible d'Alexandrie. Les Douze Prophètes. Oseé, s. 53-57.

22 A. P a s s o n i d e 1 l' A c q u a, L'edizione della versione greca-LXX-del libro di Osea, s. 317-318.

23 Na temat rękopisu Dwunastu Proroków z Nahal Hever zob. E. To v, R.A. K r a f t, P.J. P a r s o n s (red.), The Greek Minor Prophets Scroll from Nahal 
towany jest przez większość badaczy na I w. przed Chr. ${ }^{24}$ (a nawet „pierwszą połowę I w. przed Chr.”, między 100 a 50 r. przed Chr. ${ }^{25}$ ), a swoją długością zwój ten przypomina każdą z ksiąg proroków większych, co uznano także za argument przemawiający za traktowaniem Dwunastu Proroków jako całości, co czyni większość manuskryptów zawierających ten zbiór.

Tę całość dostrzegają niektórzy także w kolejności ksiąg w zbiorze $\mathrm{LXX}^{26}$ (innej nieco od TH, zwłaszcza w przypadku pierwszych sześciu ksiąg zbioru ${ }^{27}$ ). Uważają oni, że z tego powodu należy czytać księgi tego zbioru w całości i w kolejności zachowanej rękopisach LXX. W.E. Glenny zwraca uwagę, że kolejność całego zbioru Dwunastu Proroków w Kodeksie Watykańskim (B) odzwierciedla perspektywę najpierw na początku Północnego Królestwa Izraela (jako modelu dla Judy i Jerozolimy), potem zaś przenosi w kolejnych księgach nacisk na narody, by skupić się na końcu na perspektywie wyłącznie Południowej w LXX: na wybawieniu Jerozolimy i Judy. ${ }^{28}$ To dlatego Księgi: Ozeasza i Amosa (jako proroków działających na Północy) otwierałyby cały zbiór.

Dodatkowo, wiele wskazuje na to, że przekład grecki wszystkich ksiąg tzw. proroków mniejszych wyszedł spod pióra jednego tłumacza (lub jednej szkoły tłumaczy) - na co wskazuje technika przekładu,

Hever (8HevXIIgr). The Seiyâl Collection I, Discoveries in the Judean Desert 8, London 1990.

24 A. S c h a r t, Dodekapropheton. Das Zwölfprophetenbuch, s. 2276-2277.

25 R.E. Fulle r, The Form and Formation of the Book of the Twelve. The Evidence from the Judean Desert, w: J.D.W. W a t $\mathrm{s}$, J.W. W a t t s, P.R. H o u s e (red.), Forming Prophetic Literature. Essays on Isaiah and the Twelve in Honor of John D.W. Watts, Journal for the Study of the Old Testament Supplement Series 235, Sheffield 1996, s. 88.

${ }_{26}$ Tak czynił np. P.L. R e d d d i t t, The Formation of the Book of the Twelve, s. 25 .

27 J.M. D i n e s, The Minor Prophets, w: J. K. A i t k e n (red.), The T\&T Clark Companion to the Septuagint, s. 439-440; A. P a s s o n i d e 1 l' A c q u a, L'edizione della versione greca - LXX-del libro di Osea, s. 316-317.

28 W.E. G 1 e n n y, Hosea. A Commentary Based on Hosea in Codex Vaicanus, s. 2-3. 
słownictwo, styl, co szczególnie mocno podkreślił T. Mouraoka, widząc w przekładach poszczególnych ksiąg zbioru ,jedną rękę". ${ }^{29}$ I choć trwały dyskusje na ten temat (nie wszyscy zgadzali się z tą tezą), ${ }^{30}$ to przyglądając się charakterowi zmian w poszczególnych księgach zbioru w LXX, dostrzec można zarówno ich jedność, jak i fakt, że jedne księgi przełożone są wierniej (np. Księgi: Aggeusza, Nahuma, Amosa, Joela i zwłaszcza Jonasza), a inne bardziej swobodnie (Księga Ozeasza, 3 pierwsze rozdziały Księgi Micheasza czy Księga Habakuka). ${ }^{31}$ Zakładając, że przekładu dokonała grupa tłumaczy, widać w tych różnicach rolę każdego z nich. Zakładając z kolei, że tłumaczenia dokonała jedna osoba, można zauważyć jej różne nastawienie do poszczególnych ksiąg, mających przecież różny charakter, czas powstania, kontekst. ${ }^{32}$

Współczesne opracowania tematu nie są w tym względzie jednolite. Razem księgi te łączone są w wydaniach krytycznych (H.B. Swete, ${ }^{33}$ A. Rahlfs i R. Hanhart, ${ }^{34}$ J. Ziegler ${ }^{35}$ ), oraz tłumaczeniach (NETS, ${ }^{36}$ Septuaginta Deutsch, ${ }^{37}$ a także Biblia Griega - tom tłumaczenia hiszpańskiego greckich ksiąg prorockich wydany został

29 Na ten temat zob. T. M o u r a o k a, In Defence of the Unity of the Septuagint Minor Prophets, Annual of the Japanese Biblical Institute 15/1989, s. 25; podsumowanie tego tematu zob. także: B. S t r z a ł k o w s k a, Księga Aggeusza w Septuagincie, Collectanea Theologica 82(2012)4, s. 75-98, zwł. s. 93-98.

30 Zob. tamże.

31 Tamże, s. 96-97.

32 Tamże, s. 97.

33 H.B. S w e t e (red.), The Old Testament in Greek According to the Septuagint, t. II: 1 Chronicles-Tobit, The University Press, Cambridge $1922^{3}$.

34 A. R a h $1 \mathrm{f} \mathrm{s,} \mathrm{R.} \mathrm{H} \mathrm{a} \mathrm{n}$ h a r t (red.), Septuainta. Id est Vetus Testamentum graece iuxta LXX interpretes, Deutsche Bibelgessellschaft, Stuttgart $2006^{2}$.

35 J. Z i e g l e r (red.), Septuaginta. Vetus Testamentum Graecum, t. XIII: Duodecim prophetae, Göttingen 1984.

36 A. P i e t e r s m a, B.G. W r i g h t (red.), A New English Translation of the Septuagint (NETS), New York-Oxford 2007 (Dwunastu Proroków, s. 777-822).

37 W. K r a u s, M. K a r r e r, i in. (red.), Septuaginta Deutsch. Das griechische Alte Testament in deutcher Übersetzung, Deutsche Bibelgesellschaft, Stuttgart 2009 (Dwunastu Proroków, s. 1165-1229) 
w październiku $2015 \mathrm{r}^{38}$ ) oraz komentarze (np. T\&T Clark Companion to the Septuagint, pod red. J.K. Aitkena ${ }^{39}$ ).

$\mathrm{Z}$ drugiej strony, istnieją dwa duże osobne komentarze do $\mathrm{LXXOz}$ (francuski z serii La Bible d'Alexandrie ${ }^{40}$ oraz angielski w serii Septuagint Commentary Series ${ }^{41}$ ). Podobnie Septuaginta Deutsh w przekładzie traktowała księgi Dwunastu Proroków razem, ale już w komentarzu - osobno ${ }^{42}$ (opracowywały zresztą poszczególne księgi różne osoby; np. Księgę Ozeasza - E. Bons ${ }^{43}$ ). Osobno także przełożył każdą księgę i krótko skomentował R. Popowski. ${ }^{44}$

Nawet jeśli przyjmie się tezę o jednym tłumaczu całości zbioru, nie wyklucza się tym samym przyjrzenia się z osobna poszczególnym księgom, którym tłumacz nadał charakterystyczny rys. Mimo wszystko poszczególne księgi proroków mniejszych, odczytywane w konkretnym kontekście historycznym, miały nieść konkretne przesłanie, które w czasach hellenistycznych w Aleksandrii, gdy powstawał ich pierwszy (grecki) przekład, mogło być podkreślane. ${ }^{45}$ Każda z dwunastu ksiąg (nawet jako część całości) ma swoje

38 Libro de los Doce Profetas, w: La Biblia Griega. Septuaginta IV. Libros proféticos; koordynatorzy wydania: N. F e r n à n d e z M a r c o s, M. V. S p ot to r n o Dí a z - C a r o, Biblioteca de Estudios Bíblicos 128, Salamanca 2015, s. $15-123$.

39 J.M. D i n e s, The Minor Prophets, w: J. K. A i t k e n (red.), The T\&T Clark Companion to the Septuagint, s. 438-455.

${ }^{40}$ E. B o n s, J. J o o s t e n, S. K e s s le r, La Bible d'Alexandrie. Les Douze Prophètes. Oseé.

${ }^{41}$ W.E. G 1 e n n y, Hosea. A Commentary Based on Hosea in Codex Vaticanus, Leiden-Boston 2013.

${ }^{42}$ A. S c h a r t, Dodekapropheton/Das Zwölfprophetenbuch, w: Septuaginta Deutsch. Erläuterungen und Kommentare zum griechischen Alten Testament, t. II, s. 2275-2286 (wprowadzenie); komentarze do poszczególnych ksiąg tego zbioru, s. $2287-2483$.

43 E. B o n s, Osee/ Hosea, w: tamże, s. 2287-2338.

44 R. P o p o w s k i (tłum., przypisy i wstępy), Septuaginta, czyli Biblia Starego Testamentu wraz z księgami deuterokanonicznymi i apokryfami, PSB 37, Oficyna Wydawnicza „Vocatio”, Warszawa 2013.

45 B. S t r z a ł k o w s k a, Księga Aggeusza w Septuagincie, s. 97. 
charakterystyczne momenty, teologię, myśl zawartą w tym przecież najstarszym jej przekładzie.

Mogło to dotyczyć szczególnie pierwszej i najdłuższej księgi zbioru: Księgi Ozeasza. Rabini (traktat Baba Bathra 13b, 14b) mieli wątpliwości co do Księgi Ozeasza, czy nie należy jej jednak wydzielić spośród ksiąg proroków mniejszych (jako faktycznie dłuższą niż pozostałe) i nie umieścić jej na osobnym krótkim zwoju (krótkim w porównaniu z tekstem tzw. proroków większych: Izajasza, Jeremiasza czy Ezechiela). Jednak istniała pewna obawa, że taki zwój mógłby zaginąć, dlatego zdecydowano się przyłączyć go do pozostałych w zbiorze. ${ }^{46}$

Ponadto w przypadku Księgi Ozeasza przekład LXX jest tym ciekawszy, że oryginał hebrajski księgi (podobnie jak w przypadku Księgi Amosa) dzieli od przekładu LXX wiele wieków: jeżeli uznamy obie księgi hebrajskie za pochodzące z VIII/VII w., to w czasach tłumaczy LXX Księga Ozeasza (tak jak Amosa) była już wielowiekowa (liczyła ok. 500-600 lat!), a jej przesłanie mogło wydać się zrealizowane i dawne. A ponieważ Księga Ozeasza zawiera wiele ciekawych i ważnych motywów i wątków teologicznych (jak motyw małżeństwa Ozeasza, które stało się obrazem, paradygmatem relacji Boga i Izraela, czy bardzo ważny i akcentowany w księdze motyw wyjścia Izraelitów z Egiptu), które potem będą przewijać się w tradycji całego Starego Testamentu (znanego już przecież w poszczególnych księgach tłumaczom LXX), to tym bardziej warto jest przyjrzeć się charakterowi greckiego przekładu tej księgi. Ciekawostką może być fakt, że pierwsze naukowe próby porównania dwóch tradycji Księgi Ozeasza (hebrajskiej i greckiej LXX) podjęto jeszcze w czasach sprzed odkryć qumrańskich, zanim wiedza na temat rękopisów tej księgi była tak bogata jak teraz; ich autorem był G.H. Patterson. ${ }^{47}$

46 W.E. G 1 e n n y, Hosea. A Commentary Based on Hosea in Codex Vaticanus, s. 2

47 G.H. P a t t e r s o n, The Septuagint Text of Hosea Compared with the Massoretic Text, Hebraica 7/1890, s. 190-221. 


\section{Charakter przekładu LXXOz w porównaniu z TM}

Wszelkie porównania między tekstami hebrajskim i greckim są o tyle problematyczne, że nie mamy tekstu hebrajskiego (lub tekstów), na którym pracował tłumacz grecki. Fakt, że mógł on dysponować nieco innym tekstem hebrajskim niż ten, który zachował się w TM, stał się bardziej prawdopodobny, gdy odkryto hebrajskie fragmenty Księgi Ozeasza w Qumran, w grocie 4 i 5, wśród których są takie, które potwierdzają tekst LXX a nie TM, ale też i takie, które potwierdzają TM oraz nie potwierdzają żadnego z nich. ${ }^{48}$

Na przykład największy dodatek LXXOz względem TM - czyli obecne w greckim w. 13,4 nawiązanie do Boga Stworzyciela, którego nie ma TM, wydawać by się mogło ingerencją tłumacza w tekst, tymczasem w Qumran odkryto hebrajską wersję Księgi Ozeasza (oznaczoną jako 4QXII ${ }^{\text {) }}$ zawierającą również taki dodatek, ${ }^{49}$ co kazało postawić tezę, że zmiana ta wskazuje na istnienie w starożytności nieco innej wersji tego tekstu (z której najprawdopodobniej korzystał tłumacz LXXOz). Inne tego typu różnice między TM a LXX, wyjaśnione w podobny dzięki odkryciom zwojów znad Morza Martwego, dotyczą (poza w. 13,4) także ww. 2,9; 4,3; 8,6. ${ }^{50}$

Ponadto, nie mamy też jednolitego tekstu greckiego LXXOz, który w rękopisach zachował się w dwóch ważnych grupach: wspomnianych recenzjach antiocheńskiej i aleksandryjskiej, które w niewielkim stopniu, ale jednak różnią się między sobą (co widać np.

48 E. B o n s, J. J o o s t e n, S. K e s s l e r, La Bible d'Alexandrie. Les Douze Prophètes. Oseé, s. 33-35; por. także komentarz dla całego zbioru Dwunastu Proroków: D. B a r t h e 1 é m y, Critique Textuelle de l'Ancien Testament, Orbis Biblicus et Orientalis 50.3, Vandenhoeck \& Ruprecht, Göttingen 1992, s. 497-1038. Na temat tekstu Oz w Qumran zob. także opracowanie: B. E g o i in.(red.), Minor Prophets, Biblia Qumranica 3B, Brill, Leiden 2005.

49 A. P a s s o $\mathrm{n}$ i d e 1 l' A c q u a, L'edizione della versione greca-LXX-del libro di Osea, s. 320; J.M. D i n e s, The Minor Prophets, w: J. K. A i t k e n (red.), The T\&T Clark Companion to the Septuagint, s. 438.

50 E. B o n s, J. J o o s t e n, S. K e s s 1 e r, La Bible d'Alexandrie. Les Douze Prophètes. Oseé, s. 33. 
w 33 cytatach Dwunastu Proroków w Nowym Testamencie). ${ }^{51}$ Najwyraźniej sytuacja tekstualna Księgi Ozeasza była już na etapie powstawania Nowego Testamentu płynna i złożona, skoro cytaty pochodzą z różnych tradycji, co jednak czyni analizę tekstualną tej księgi w LXX (i TM) tym ciekawszą.

Lepiej zatem mówić o ró ż n i c a c h między LXX a TM, który odtwarzamy, nie zaś zawsze o z m i a n a ch. Śledząc tekst grecki Księgi Ozeasza i porównując go z hebrajskim, w wersjach, jakie mamy, można dość dokładnie wnioskować, jakiego pochodzenia jest dana różnica: czy pochodzi z ingerencji tłumacza, ze zmiany gramatycznej czy ideologicznej, powstała w wyniku błędu czy też jest rezultatem innego możliwego hebrajskiego Vorlage.

Najczęściej, co trzeba podkreślić, zmiany i różnice między tekstami hebrajskim i greckim Księgi Ozeasza powstały w procesie jej przekładu na język grecki. ${ }^{52} \mathrm{~A}$, jak zaznaczono na samym początku, przekład LXX (w stanie, jakim go mamy; wydania krytyczne zazwyczaj biorą pod uwagę Kodeks Watykański jako punkt wyjścia do analiz) jest zasadniczo bardzo wierny tekstowi hebrajskiemu, ma jednak zarazem pewne cechy charakterystyczne i różnice, na które warto zwrócić uwagę (ta zasada dotyczy zarówno Księgi Ozeasza, jak i pozostałych w zbiorze Dwunastu Proroków).

Można te cechy charakterystyczne i różnice podzielić na kilka grup: różnice wynikające z błędów w odczytaniu hebrajskiego tekstu, różnice gramatyczne, tzw. braki i dodatki, czy - najciekawsze zmiany intencjonalne tłumacza. Wszystkie one są interesujące, tym bardziej że archaiczny język księgi hebrajskiej, liczący w czasach tłumacza już wiele wieków, a do tego poetycki charakter księgi, sprawił, że tłumacz musiał zmierzyć się z materiałem niełatwym w przekładzie.

51 Tamże, s. 51-52; J.M. D i n e s, The Minor Prophets, w: J. K. A i t k e n (red.), The T\&T Clark Companion to the Septuagint, s. 451-452.

52 E. B o n s, J. J o o s t e n, S. K e s s l e r, La Bible d'Alexandrie. Les Douze Prophètes. Oseé, s. 33; por. A. P a s s o n i d e 1 l' A c q u a, L'edizione della versione greca-LXX-del libro di Osea, s. 321. 
Mimo to, trzeba powiedzieć, że najważniejszą cechą charakterystyczną przekładu LXXOz jest wierność także co do sensu tekstu hebrajskiego oryginału. ${ }^{53} \mathrm{Sac}$ w tekście greckim obecne nawet hebraizmy, typowe dla $\mathrm{LXX},{ }^{54}$ ale najlepszym przykładem takiego tłumaczenia są imiona trojga dzieci Ozeasza (Oz 1), które w LXX oddano nie fonetycznie, a znaczeniowo (a przecież właśnie zrozumienie ich znaczenia było w nich kluczowe do interpretacji przesłania całej tej części księgi): i tak imię pierwszego syna - יְרעׁאל (Jizreel; z 1,4) - w LXX brzmi I $€ \rho \alpha \in \lambda$; ale już imię córki - לא רְחמה (Lo Ruchama; z 1,6; jej imię oznacza „Bez miłosierdzia”) - brzmi po

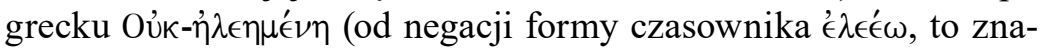
czy ,okazywać miłosierdzie”); zaś imię trzeciego syna - ליא עַפְִּ (Lo Ammi - „Nie mój lud”; z 1,9) - w LXX brzmi: Oủ- $\lambda \alpha o ́ \varsigma-\mu o v$, zgodnie ze znaczeniem hebrajskim. Taka praktyka nieużywania transliteracji jest obecna w całym zbiorze Dwunastu Proroków w LXX i m ożna ją nazwać typową cechą przekładu. ${ }^{55}$

Skoro całość Księgi Ozeasza przełożona jest wiernie, tym bardziej warto przyjrzeć się wspomnianym grupom różnic.

Różnice między TM a LXX wynikające z błędów w odczytaniu hebrajskiego tekstu

W przekładzie występują dwa typy takich różnic: jedne dotyczą tekstu samogłoskowego, drugie - tekstu spółgłoskowego. ${ }^{56}$

53 Por. J.M. D i n e s, The Minor Prophets, w: J. K. A i t k e n (red.), The $T \& T$ Clark Companion to the Septuagint, s. 440; E. B o n s, J. J o o s t e n, S. K e s s 1 e r, La Bible d'Alexandrie. Les Douze Prophètes. Oseé, s. 43.

54 Por. J.M. D i n e s, The Minor Prophets, w: J. K. A i t k e n (red.), The T\&T Clark Companion to the Septuagint, s. 441; E. B o n s, J. J o o s t e n, S. K e s s 1 e r, La Bible d'Alexandrie. Les Douze Prophètes. Oseé, s. 44-46.

55 J.M. D i n e s, The Minor Prophets, w: J. K. A i t k e n (red.), The T\&T Clark Companion to the Septuagint, s. 442-443.

56 Ich prawie pełną listę zob. A. K a m i n k a, Studien zur Septuaginta an der Hand der zwölf kleinen Prophetenbücher, Monatsschrift für Geschichte und 
W tekście samogłoskowym - chodzi o terminy odczytane w LXX z i nną wokalizacją niż ta, którą poda późniejszy TM. ${ }^{57}$ Chodzi np. o w. 3,1, gdzie w zdaniu: „Pokochaj jeszcze raz kobietę,

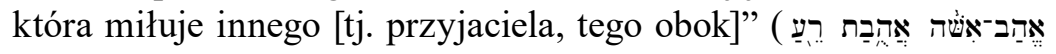

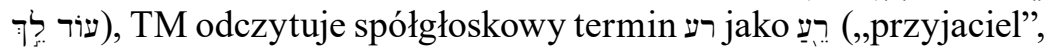
„towarzysz”, także „bliźni”, ,ten obok”), zaś LXX wokalizuje go jako רִ (,to, co złe"), przekładając to zdanie z greckim rzeczowni-

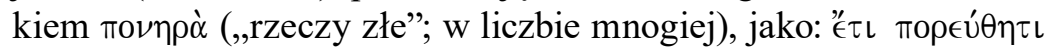

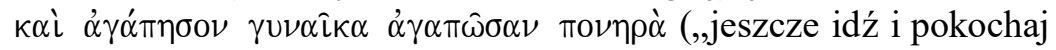
kobietę, która miłuje to, co złe"). ${ }^{58}$ Taką interpretację, jak w LXX, wychwycił także Talmud Babiloński, uważając, ze tekst hebrajski niewokalizowany zawiera tu swoistą grę słowną, bazującą na obu znaczeniach רע (traktat Chagiga 16A). ${ }^{59}$

Inne tego typu różnice w odczytaniu wokalizacji można znaleźć jeszcze w wersetach: 1,4; 2,13.15; 7,5; 8,5; 9,1.3.12; 10,1; 11,5.7.10; $13,1.2 .7 .8 .9 ; 14,4.8 .^{60}$

Naturalnie w LXXOz są także przykłady odczytanego tekstu samogłoskowego tak, jak późniejsza tradycja masorecka, np. w bliskim kontekście podanego przykładu, w ww. 3,4-5, gdzie chodzi o tak samo zapisane spółgłoskowo (różni je jedynie wokalizacja) podobne

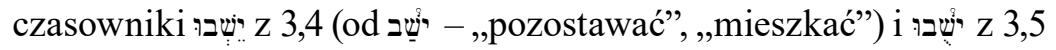
(od שוב -,powracać"). LXX odczytała je dokładnie tak, jak TM,

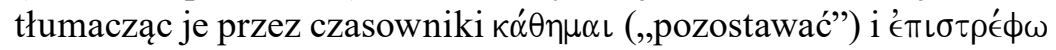
(,powracać”) - choć o błąd w tym przypadku było łatwo, gdyż w niewokalizowanym tekście oba czasowniki wyglądają identycznie. ${ }^{61}$

Wissenschaft des Judentums 72/1928, s. 245-255; por. E. B o n s, J. J o o s t e n, S. K e s s 1 e r, La Bible d'Alexandrie. Les Douze Prophètes. Oseé, s. 38

${ }^{57}$ E. B o n s, J. J o o s t e n, S. K e s s l e r, La Bible d'Alexandrie. Les Douze Prophètes. Oseé, s. 34.

58 Tamże.

59 A. K a m i n k a, Studien zur Septuaginta an der Hand der zwölf kleinen Prophetenbücher, s. 242-273, zwł. s. 261; por. E. B o n s, J. J o o s t e n, S. K e s s 1 e r, La Bible d'Alexandrie. Les Douze Prophètes. Oseé, s. 34.

${ }^{60}$ Tamże.

${ }^{61}$ Por. na ten temat: tamże. 
Różnice w odczytanie tekstu spółgłoskowego są równie ciekawe $\mathrm{i}$ jest ich więcej. Zdarzało się tłumaczom LXX mylić podobne hebrajskie litery: np. ᄀ i า (Oz 2,12; 7,14; 9,2.7.13; 10,7.11.14; 11,7; 13,5); १ i ,

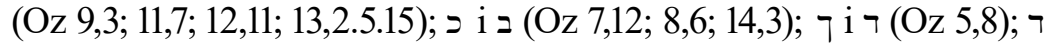

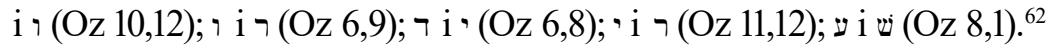

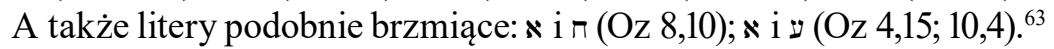

Są też w LXXOz bardzo liczne przykłady innego (lub błędnego) odczytania rdzeni hebrajskich (świadectwo prawie 20 takich rdzeni podaje La Bible d'Alexandrie ${ }^{64}$ ). Na przykład w Oz 5,5 czy 7,10 tłumacz LXX oddał rdzeń ענה II (,upokorzyć"), a nie, sugerowany przez kontekst tekstu hebrajskiego, rdzeń ענה I (,odpowiedzieć”), tłumacząc ten termin przez gr. $\tau \alpha \pi \epsilon \iota \nu$ ó $\omega .{ }^{65}$ Zmiany o charakterze błędu w odczytaniu tekstu hebrajskiego są zatem w LXXOz dość częste. ${ }^{66}$

\section{Różnice gramatyczne}

Obok wspomnianych różnic terminologicznych, wynikających z błędnego odczytania tekstu hebrajskiego (czy to spółgłoskowego, czy samogłoskowego), są obecne między tekstem LXX, a TM także różnice gramatyczne. Chodzi o dodatki rozmaitych drobnych form gramatycznych, ujednolicanie czasów, które konieczne było przy przekładzie z języka semickiego na język o zupełnie innym charakterze, jakim jest język grecki. Te zmiany nie zmieniają zasadniczo przesłania tekstu, ale czynią go bardziej przystępnym dla czytelnika greckiego, objaśniają i ujednolicają tekst.

62 Zob. A. K a m i n k a, Studien zur Septuaginta an der Hand der zwölfkleinen Prophetenbücher, s. 245-255; E. B o n s, J. J o o s t e n, S. K e s s 1 e r, La Bible d'Alexandrie. Les Douze Prophètes. Oseé, s. 38.

63 Tamże.

64 Tamże, s. 38-39.

65 Wspomina o nich także J.M. D i n e s, The Minor Prophets, w: J. K. A i t k e $\mathrm{n}$ (red.), The T\&T Clark Companion to the Septuagint, s. 443.

${ }^{66} \mathrm{~A} . \mathrm{P}$ a s s o $\mathrm{n}$ i d e 1 l' A c q u a, L'edizione della versione greca $-L X X-$ del libro di Osea, s. 321. 
Tego typu różnic, najbardziej wyraźnych, jest w księdze ponad $30 .{ }^{67}$ Pojawiają się w LXX nieobecne w posiadanym przez nas TH przyimki (np. w: Oz 10,14; 12,9; 13,6), ${ }^{68}$ spójniki (np. w: Oz 8,3.13; 9,1; 10,13; 14,1.10), ${ }^{69}$ zaimki osobowe (np. w: 1,10; 2,8; 9,14; 11,1.7; 14,1) oraz dzierżawcze (np. Oz 9,7). ${ }^{70}$

Ponadto w zdaniach greckich pojawiają się nieobecne w TM

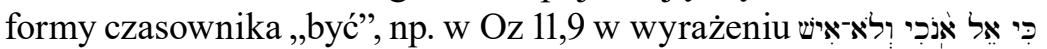
(dosł. „Ponieważ Bogiem ja, nie człowiekiem”), które po grecku

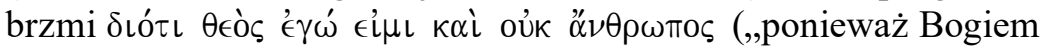
ja j e s t e m, a nie człowiekiem”). Inne tego typu zmiany występują jeszcze w Oz 2,7; 5,14; 9,12. ${ }^{71}$

Wszystkie gramatyczne zmiany miały na celu ujednolicenie tekstu hebrajskiego, co często zdarzało się tłumaczom czy rewizorom $\mathrm{TH}$ w LXX. W przypadku Księgi Ozeasza wszystkie tego typu zmiany zostały odnotowane przez H.-D. Neefa. ${ }^{72}$

\section{„Dodatki” i ,braki” LXXOz względem TM}

Obok omówionych dodatków gramatycznych (zazwyczaj niewielkich), niewątpliwie najbardziej widoczną grupą różnic w LXX względem TM są tzw. dodatki i braki LXXOz, przy czym nazewnictwo to jest umowne i odnosi się do tekstów (zarówno hebrajskiego, jak i greckiego) przyjętych we współczesnych wydaniach krytycznych, ze świadomością, że nie wszystkie różnice tego typu między tekstami są dziełem tłumacza, a czasem to, co wydaje się „dodatkiem” LXX, jest de facto „brakiem” w TM i odwrotnie.

${ }^{67}$ Por. E. B o n s, J. J o o s t e n, S. K e s s 1 e r, La Bible d'Alexandrie. Les Douze Prophètes. Oseé, s. 35-36

68 Tamże, s. 35.

69 Por. tamże.

70 Por. tamże.

71 Por. tamże.

72 Pełną listę tego typu zmian zob. H.-D. N e e f, Der Septuaginta-Text und der Masoreten-Text des Hoseabuches im Vergleich, Biblica 67/1986, s. 195-220, zwł. s. 196-199. 
W przypadku LXXOz tego typu zmian jest niewiele, ponieważ dołożono starań, by przekład był jak najbardziej wierny oryginałowi. Ponieważ jednak tego typu zmian jest mniej - tym są one ciekawsze w interpretacji. Trzeba podkreślić, że w przypadku Księgi Ozeasza w LXX większość z nich stanowią różnice, które można potraktować jak zmiany w prowadzone przez tłumacza. Są to zmiany intencjonalne (w przeciwieństwie do wspomnianych błędów) i wynikają z indywidualnej pracy translatorskiej. Często mają charakter teologiczny, ideologiczny, środowiskowy (chodzi o grupę, dla której tłumacz przygotowywał swoje tłumaczenie, która żyła w innym kontekście geograficznym i historycznym niż autor hebrajskiej Księgi Ozeasza) i dają się wyjaśnić na różne sposoby.

Pierwszą grupą tego typu ,dodatków” są zmiany dokonane w LXX pod wpływem innych miejsc w Starym Testamencie. Chodzi o teksty paralelne w innych księgach, które tłumacz ujednolicił z tekstem Księgi Ozeasza. Takie przykłady mamy w: Oz 1,7 (gdzie mowa w LXX o rydwanach); 2,8; 2,12 i 4,3 (o zwierzętach ziemi); 8,13 (o Asyryjczykach); 11,5 (dodatek terminu „Efraim”); 12,9 i 13,4. ${ }^{73}$ Tłumacz chciał tekst ujednolicić z innymi częściami Starego Testamentu, a zmiany mają charakter intencjonalny.

Drugą grupą są podobne dodatki pojedynczych słów bądź wyrażeń jednak bez wpływu innych ksiąg. Powodem ich wprowadzenia do LXX jest chęć, by kontekst wypowiedzi stał się bardziej jasny. Przykładem takiego dodatku może być w. 4,2, gdzie LXX dodaje

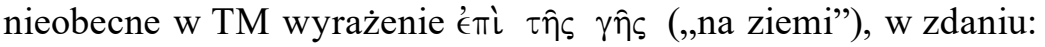
„Przeklinają, kłamią, mordują i kradną, cudzołożą, popełniają gwałty $\mathrm{n}$ a $\mathrm{z}$ i e $\mathrm{m}$ i, a zbrodnia idzie za zbrodnią"). Inne tego typu zmiany występują jeszcze w: 4,17; 5,11.13; 7,6; 11,12; 13;8; 14,8; a w ww. 6,1 oraz 14,3 uzupełniony jest termin кúpıoৎ („Pan”) o dodatek „nasz/wasz

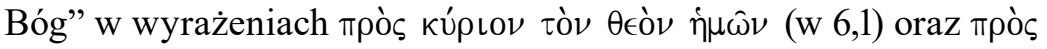

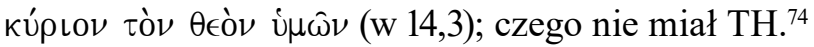

73 Por. E. B o n s, J. J o o s t e n, S. K e s s 1 e r, La Bible d'Alexandrie. Les Douze Prophètes. Oseé, s. 35-36.

74 Tamże, s. 36. 
Za trzecią grupę można uznać przypadki tzw. braków, gdy LXXOz omija jakieś niejasne słowo hebrajskie. Zmiany tego typu nie są liczne, i można wśród nich znaleźć zmiany mniejsze, gramatyczne (usunięcie zaimka osobowego z w. 4,13; czy spójnika z ww. 3,3 i 4,3), ${ }^{75}$ a także ominięcia terminów w sytuacji, gdy w wersecie hebrajskim dwukrotne jakieś słowo jest powtórzone (wówczas LXX pozostawia je tylko jedno): np. w ww.: 2,21; 5,14; 10.15 (i ew. jeszcze w w.8,2 wraz z 8,3; oraz 7,15 wraz z 7,14). ${ }^{76}$

Pozostałe zmiany intencjonalne tłumacza

Te wymienione cechy charakterystyczne i różnice intencjonalne są jednak drobne, i zasadniczo nie zmieniają interpretacji tekstu księgi, a raczej go ujednolicają i objaśniają. Są jednak obecne w tekście LXXOz zmiany intencjonalne tłumacza o większym znaczeniu (i nie ma w ich przypadku wątpliwości, że nie są one wynikiem innego Vorlage tekstu).

Charakterystyczną cechą przekładu LXX w ogóle (znajdującą wyraz także w greckiej Księdze Ozeasza) jest unikanie personifikacji. ${ }^{77}$ Przykładem takiej zmiany może być w. 4,12, gdzie hebrajskie

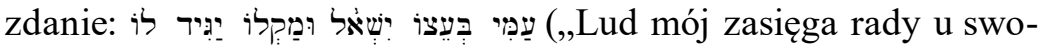
jego drzewa, a jego kij daje mu wyrocznię") przełożono na grecki

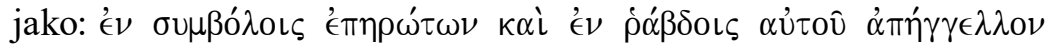

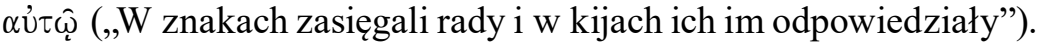
Podobne zmiany dotyczą ww.: 5,4; 4,2.11-12. ${ }^{78}$ Są one z pewnością podyktowane chęcią obrony monoteizmu przed jakimikolwiek skojarzeniami z kultami pogańskimi.

75 Por. tamże. Pełną listę tego typu zmian zob H.-D. N e e f, Der Septuaginta-Text und der Masoreten-Text des Hoseabuches im Vergleich, s. 195-220, zwł. s. 199-200.

76 Por. E. B o n s, J. J o o s t e n, S. K e s s 1 e r, La Bible d'Alexandrie. Les Douze Prophètes. Oseé, s. 36-37.

77 Por. tamże, s. 41.

78 Por. tamże. 
Szczególnie interesująca większa zmiana intencjonalna, szczególnie istotna w kontekście LXXOz, wiąże się z tekstami mówiącymi o Egipcie.

Na pewną konsekwencję w postrzeganiu Egiptu w LXXOz zwrócił uwagę jako pierwszy prof. Stephen Pisano, ${ }^{79}$ a myśl tę rozwinął później Edward Glenny na zjeździe IOSOT w Helsinkach w 2010 r. ${ }^{80}$ Wspominają oni, że w Księdze Ozeasza na 13 przypadków, gdzie wspominany jest Egipt w tekście hebrajskim (ww. 2,15; 7,11.16; 8,13; 9,3.6; 11,1.5.11; 12,1.9.13; 13,4), mowa jest o nim w odniesieniu do przyszłości (jako zapowiedź); a w aż $7 \mathrm{z}$ nich tłumacz LXX zmienił to odniesienie czasowe, tak by nie było ono przyszłym doświadczeniem Izraelitów (jak to jest w TM), ale przeszłym lub już zrealizowanym (!), z perspektywy proroka Ozeasza. ${ }^{81}$ Tłumacz LXXOz przedstawił grzeszny Izrael, jako pozostający w Egipcie w czasach proroka Ozeasza, a nie mający udać się do Egiptu. Kilka przykładów:

- Oz 8,13:

TM:

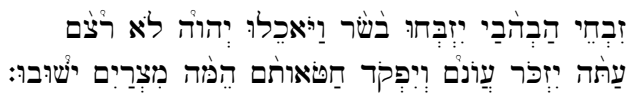

„Lubią ofiary krwawe i chętnie je składają, lubią też mięso, które wówczas jedzą, lecz Pan nie ma w tym upodobania.

79 S. P i s a n o, „Egypt” in the Septuagint Text of Hosea, w: G.J. N o r t o n, S. P i s a no, D. B a r thé le m y, C.M. M a r t i n i (red.), Tradition of the Text: Studies offered to Dominique Barthélemy in Celebration of his 70th Birthday, Orbis Biblicus et Orientalis 109, Vandenhoeck \& Ruprecht, Fribourg-Göttingen 1991, s. 301-308.

${ }^{80}$ W.E. G 1 e n n y, Ephraim Dwelt in Egypt: Egypt and Assyria in the Septuagint of Hosea, w: M. K.H. P e t e r s (red.), XIV Congress of the IOSCS, Helsinki, 2010, Septuagint and cognate studies 59, Society of Biblical Literature, Atlanta 2013, s. 457-471.

${ }^{81}$ W pozostałych wersetach, które nie zmieniają tego odniesienia czasowego $(2,15 ; 12,9.13 ; 13,4)$, Oz nawiązuje już do przeszłości: do wyjścia Izraelitów z Egiptu (wydarzenie przeszłe, zarówno z perspektywy Ozeasza, jak i tłumacza). 
Teraz wspomnę na ich przewinienia i ukarzę ich za grzechy niech wrócą znów do Egiptu!"

\section{LXX:}

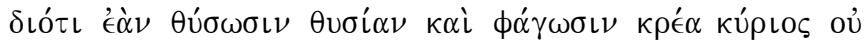

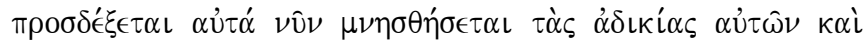

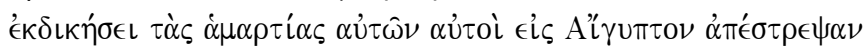

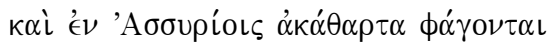

„Lubią ofiary krwawe i chętnie je składają, lubią też mięso, które wówczas jedzą, lecz Pan nie ma w tym upodobania. Wspominam wtedy na ich przewinienia i karzę ich za grze-

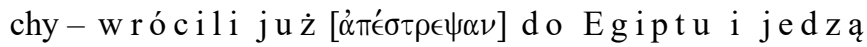
nieczyste rzeczy między Asyryjczykami”.

Podobnie pozostałe teksty (TM w p rzekładzie za BT):

- Oz 9,3: TM - „Nie będą oni mieszkać dłużej w ziemi Pańskiej, Efraim wróci do Egiptu - w Asyrii będą jedli pokarmy nieczyste”; LXX - „Nie będą oni mieszkać dłużej w ziemi

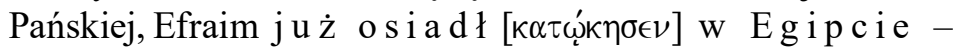
w Asyrii jedzą pokarmy nieczyste”.

- Oz 9,6: TM - ,Tak, oni muszą wędrować do Asyrii; Egipt ich zbierze, a Memfis pogrzebie, oset pokryje skarby ich ze srebra, a ich namioty porosną cierniami”; LXX - „Tak, oni muszą

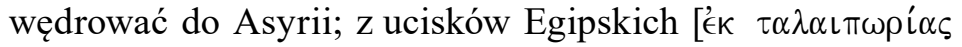

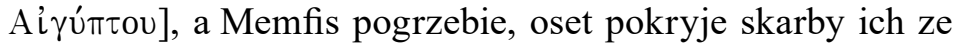
srebra, a ich namioty porosną cierniami”.

- Oz 11,5: TM - „Powrócą do Egiptu i Aszszur będzie ich królem, bo się nie chcieli nawrócić”; LXX - „O sied lił się

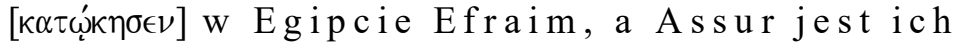
królem, bo nie chcieli się nawrócić".

Podobnie jest w pozostałych tekstach LXX. Tłumacz zmienia czas na przeszły, ukazując i podkreślając, że Izraelici są w Egipcie, bo nie chcieli się nawrócić. 
Takie podejście mogło być związane z sytuacją samego tłumacza/ tłumaczy, którzy, żyjąc w kontekście Egiptu w Aleksandrii, w sposób szczególny mogli odnosić się do wątków i tradycji dotyczących Egiptu. Podkreślenie obecności w Egipcie i Asyrii - jako wyniku grzechu Izraela - mogło wyjaśniać sytuację Żydów żyjących w diasporze, przyczynę rozproszenia w różne części świata (do Mezopotamii, do Egiptu, gdzie istniały przecież prężnie rozwijające się diaspory w okresie hellenistycznym).

Szukając przyczyn tego rozproszenia, tłumacz mógł objaśnić sytuację w ten sposób, odnosząc ją nie do zapowiedzi, a do jej realizacji. A jego swoboda w przekładzie dodatkowo pozwalała zaktualizować przesłanie Księgi Ozeasza do sytuacji Żydów aleksandryjskich, do których kierowany był przekład księgi.

W.E. Glenny zauważa także, że przykłady te są analogiczne do innych tekstów Dwunastu Proroków, gdzie zmienia się czas: chodzi np. o aktualizację dotyczącą Syrii i Samarii w LXXAm oraz aktualizację dotyczącą Jerozolimy w LXXZa (co mogłoby poświadczać także jednego tłumacza lub jedną szkołę przekładu wszystkich proroków mniejszych). ${ }^{82}$

J.M. Dines wspomniane zmiany z ww. 8,13 i 9,3 interpretuje jako właściwą tłumaczowi LXXOz harmonizację, ${ }^{83}$ zaś zmianę z w. 11,1 (gdzie w miejsce ,syna” LXX ma ,dzieci”) traktuje jako postawienie akcentu mesjanistycznego, obecnego w całym zbiorze Dwunastu Proroków w LXX. ${ }^{84}$

Badacze zwracają uwagę na inne zmiany o charakterze intencjonalnym, zwłaszcza teologicznym, np. w ww. 8,4; 2,2-3; 3,4; 9,12. ${ }^{85}$

82 W.E. G 1 e n n y, Ephraim Dwelt in Egypt: Egypt and Assyria in the Septuagint of Hosea, w: M. K.H. P e t e r s (red.), XIV Congress of the IOSCS, Helsinki, 2010, s. 470-471; por. J.M. D i n e s, The Minor Prophets, w: J. K. A i t k e n (red.), The T\&T Clark Companion to the Septuagint, s. 447.

83 Tamże, s. 443.

${ }^{84}$ Tamże, s. 448.

${ }^{85}$ A. P a s s o n i d e 1 l' A c q u a, L'edizione della versione greca-LXX-del libro di Osea, s. 322. 
Inni opracowują tekst LXXOz na sposób egzegetyczny. ${ }^{86}$ Jeszcze inni podkreślają, że w tekście LXXOz można znaleźć inne drobniejsze zmiany interpretacyjne tekstu o charakterze przypominającym interpretacje rabiniczne - np. w ww. 10,12; 11,12 ${ }^{87}$ lub ww. 8,1; 12,12; 13,1. ${ }^{88}$ Zauważa się również obecne w LXXOz tłumaczenia arameizujące. ${ }^{89}$ Egzegeci podejmują także wątki bardziej szczegółowe dotyczące LXXOz (zwłaszcza poszczególnych problematycznych lub bardziej interesujących wersetów) - wśród najczęściej publikujących na temat LXXOz badaczy w początkach XXI wieku są: E Bons, ${ }^{90}$

86 J. J o o s t e n, Exegesis in the Septuagint version of Hosea, w: J.C. de M o o r (red.), Intertextuality in Ugarit and Israel. Papers Read at the Tenth Joint Meeting of the Society for Old Testament Study and het Oudtestamentisch werkhezelschap in Nederland en Belgie held at Oxford, 1997, Leiden-Boston-Köln 1998, s. $62-85$.

87 Por. A. K a m i n k a, Studien zur Septuaginta an der Hand der zwölfkleinen Prophetenbücher, s. 255-263; E. B o n s, J. J o o s t e n, S. K e s s 1 e r, La Bible d'Alexandrie. Les Douze Prophètes. Oseé, s. 37.

${ }^{88}$ Tamże, s. 38; por. A. P a s s o n i d e 1 l' A c q u a, L'edizione della versione greca-LXX-del libro di Osea, s. 321.

89 E. B o n s, J. J o o s t e n, S. K e s s 1 e r, La Bible d'Alexandrie. Les Douze Prophètes. Oseé, s. 39-40; por. A. P a s s o n i d e 1 l' A c q u a, L'edizione della versione greca - LXX-del libro di Osea, s. 321.

90 Jego publikacje niejednokrotnie są przedrukowywane w innym języku:

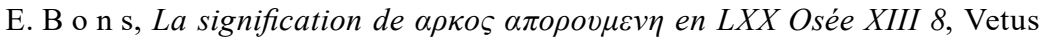
Testamentum 51/2001, s. 1-8; t e n ż e, ,Je suis votre éducateur” (Osée 5,2 LXX): un titre divin et son contexte littéraire, $\mathrm{w}$ : $\mathrm{t}$ e $\mathrm{n} \dot{\mathrm{z}} \mathrm{e}$ (red.), Le jugement dans l'un et l'autre Testament, Paris 2004, s. 191-206; t e n ż e, Une vache folle dans la Bible? La comparaison $\omega \varsigma \delta \alpha \mu \alpha \lambda \iota \varsigma \pi \alpha \rho o \imath \sigma \tau \rho \omega \sigma \alpha \pi \alpha \rho \circ \sigma \tau \rho \eta \sigma \varepsilon v$ I $\sigma \rho \alpha \eta \lambda(O s 4,16 L X X)$ et son arrière-fond littéraire, w: D. B ö h 1 e r (red.), L'écrit et l'esprit, Fribourg 2005, s. 30-37; t e n ż e, A Mad Cow in the Bible? The Simile $\dot{\varsigma} \delta \dot{\alpha} \mu \alpha \lambda \iota \varsigma \pi \alpha \rho o l \sigma \tau \rho \tilde{\omega} \sigma \alpha$ $\pi \alpha \rho o i \sigma \tau \rho \eta \sigma \varepsilon v$ I $\sigma \rho \alpha \eta \lambda$ (Hos 4,16LXX) and Its Literary Background, w: t e $\mathrm{n} \dot{\mathrm{z}} \mathrm{e}$ (red.), Textkritik und Textgeschichte: Studien zur Septuaginta und zum hebräischen Alten Testament, Forschungen zum Alten Testament 93,Tübingen 2014, s. 149-155; t e n ż e, The significance of $\Omega \Sigma A P K O \Sigma$ AПOPOYMENH in Hos 13,8LXX; w: tamże, s. 157-163. 
a wcześniej, czyli w ostatnich dekadach XX wieku T. Mouraoka, ${ }^{91}$ ale $\mathrm{i}$ inni. ${ }^{92}$

Podsumowując rozważania na temat charakteru przekładu LXXOz, trzeba podkreślić, że najważniejszą charakterystyką przekładu Księgi Ozeasza - podobnie jak pozostałych ksiąg Dwunastu Proroków - jest wierność oryginałowi hebrajskiemu, co do sensu i przesłania, choć zarazem tekst ten zawiera ciekawe ingerencje i zmiany oraz coś, co można nazwać ,interpretacją aktualizacyjną”, ujednolicająca tekst, ale także udostępniającą go czytelnikowi, dla którego przekład był przeznaczony (żyjącemu w innym kontekście kulturowym i innych czasach niż autor hebrajskiej księgi). Przekład LXX miał doprecyzować i zaktualizować tekst Księgi Ozeasza. ${ }^{93}$

Podczas tej pracy translatorskiej nie ustrzeżono (wspomnianych i wyliczonych) błędów także w odczytaniu tekstu hebrajskiego (zarówno tekstu spółgłoskowego, poszczególnych rdzeni, jak i wokalizacji), dokonano mniej istotnych, gramatycznych zmian w tekście.

91 Obok cytowanych już artykułów, pojawiło się kilka jego prac egzegetycznych dot. LXXOz: T. M o u r a o k a, Hosea IV in the Septuagint Version, Annual of the Japanese Biblical Institute 9/1983, s. 24-64; t e n ż e, Hosea $V$ in the Septuagint Version, Abr-Nahrain 24/1986, s. 120-138; T e n ż e, Hosea III in the Septuagint Version, w: J. D a v i e s, G. H a r v e y, W.G.E. W a t s o n, J.F.A. S a w y e r (red.), Words Remembered, Texts Renewed, Journal for the Study of the Old Testament Supplement Series 195, Sheffield 1995, s. 242-252; t e n ż e, Hosea 6 in the Septuagint, w: H. A u s 1 o o s, B. L e m m e 1 i j n, M. V e r v e n n e (red.), Florilegium Lovaniense. Studies in Septuagint and Textual Criticism in Honour of Florentino García Martínez, Bibliotheca Ephemeridum Theologicarum Lovaniensium 224, Leuven-Paris-Dudley 2008, s. 335-349.

92 T. M e a d o w c r o f t, $\kappa \alpha \tau \alpha \sigma \tau \rho o \varphi \eta:$ A Puzzling LXX Translation Choice in Hosea VIII 7A, Vetus Testamentum 46/1996, s. 539-543; E.G. D a f n i, $\Sigma \alpha \rho \xi \mu$ ov $\varepsilon \xi \alpha v \tau \omega v$ (LXX-Hosea ix, 12): Zur Theologie der Sprache der Septuaginta, Vetus Testamentum 51/2001, s. 336-353; H.-D. N e e f, Das Hoseabuch im Spiegel der Septuaginta: Aspekte der Deutung, w: T.S. C a u 11 e y, H. L i c h t e n b e r g e r (red.), Die Septuaginta und das frühe Christentum. The Septuagint and Christian Origins, Wissenschaftliche Untersuchungen zum Neuen Testament 277, Tübingen 2011, s. 106-118.

93 Na ten temat zob. W.E. G 1 e n n y, Hosea. A Commentary Based on Hosea in Codex Vaicanus, s. 20-22. 
Interesujące jest także, że tych rozmaitych różnic między TM a LXX jest mniej w tekście rozdziałów 1-3, kluczowych do rozumienia przeslania Ozeasza (mówiących o historii małżeństwa Ozeasza z Gomer), a zdecydowanie więcej w rozdziałach 4-10, których przesłanie i treść są bardziej złożone.

Przy tych licznych rozbieżnościach między TM a LXX wiele jednak przemawia za tym, że autorem owych błędów i zmian był w większości sam tłumacz (tłumacze LXX), a rzadziej odmienny tekst hebrajski, który stanowił podstawę greckiego przekładu. Taka tendencja coraz częściej zauważana jest w interpretacji ksiąg LXX. ${ }^{94}$ Nawet E. Tov, rozważając znaczenie LXX dla krytyki tekstualnej Biblii Hebrajskiej, zauważył, że choć są tysiące różnic między Tekstem Masoreckim a przekładem greckim hebrajskiego tekstu w LXX, to tylko niewielka ich część może być związana z innym Vorlage tekstu. ${ }^{95}$ Większość jest jednak sprawą tłumacza (tłumaczy).

\section{Data i miejsce powstania greckiej wersji Ksiegi Ozeasza}

W konsekwencji dyskusji nad tekstem LXXOz i jego charakterem, pojawiło się także pytanie o datę i miejsce działalności tłumacza (tłumaczy) księgi, a może całego zbioru Dwunastu Proroków, który ona otwiera (jeśli uznamy, że cały zbiór wraz z LXXOz wyszedł spod pióra jednego tłumacza). O ile miejsce powstania raczej nie budzi wątpliwości (Aleksandria, na którą wskazuje terminologia znana w Egipcie okresu hellenistycznego, ${ }^{96}$ a także wspomniane

$94 \mathrm{Na}$ temat tych tendencji zob. np. M. R ö s e 1, Translators as Interpreters. Scriptural Interpretation in the Septuagint, w: M. H e n z e (red.), A Companion to Biblical Interpretation in Early Judaism, Grand Rapids Mi-Cambridge 2012, s. 64-91.

95 E. To v, Textual Criticism of the Hebrew Bible, Minneapolis 1992, s. 123; zob. t e $\mathrm{n} \dot{\mathrm{z}} \mathrm{e}$, The Text-Critical Use of the Septuagint in Biblical Research, Jerusalem Biblical Studies 8, Jerozolima $1997^{2}$ (poprawione i poszerzone).

96 J. M. D i n e s, The Minor Prophets, w: J. K. A i t k e n (red.), The T\&T Clark Companion to the Septuagint, s. 441. Na ten temat także: W. E. G 1 e n n y, Hosea. A Commentary Based on Hosea in Codex Vaicanus, s. 19-20. 
interpretacje Egiptu w LXXOz), o tyle bardzo trudno jednoznacznie określić dokładną datę powstania przekładu. Istnieją jednak pewne wskazówki zewnętrzne i wewnętrzne, które pozwalają na określenie przynajmniej pewnej granicy czasowej, kiedy ów grecki przekład Księgi Ozeasza mógł powstać.

Podpowiedzią mogą być manuskrypty tego zbioru, z których najstarszy jest wspomniany już tekst Dwunastu Proroków odnaleziony w Nahal Hever (8HevXIIgr), datowany przez większość badaczy na I w. przed Chr. Przekład LXXOz musiał zatem powstać jeszcze wcześniej.

Istnieje też wśród badaczy zgodność co do tego, że przekład ksiąg Dwunastu Proroków (a zatem i LXXOz) zdecydowano się zrobić W dość wczesnej fazie przekładów greckich ksiąg biblijnych. ${ }^{97}$ Wskazuje na to język, słownictwo, zastosowana technika przekładu, wskazująca na czas III-I w. przed Chr. ${ }^{98}$ Jeśli zatem przekładano zbiór zaraz po Pięcioksięgu, ${ }^{99}$ trzeba przyjąć, że mógł to być III lub II w. przed Chr. (badacze częściej opowiadają się za II w. przed Chr. przed lub po Powstaniu Machabejskim). ${ }^{100}$

Co istotne, taka datacja sprawia, że przekład LXXOz może stanowić zarazem pierwsze świadectwo interpretacji Księgi Ozeasza, powstałe ponad 500 lat po jej hebrajskim oryginale.

Barbara STRZALKOWSKA

97 Tamże, s. 18.

98 J. M. D i n e s, The Minor Prophets, w: J. K. A i t k e n (red.), The T\&T Clark Companion to the Septuagint, s. 441.

99 Na temat datacji Pięcioksięgu w LXX, zob. B. S t r z ał k o w s k a, Księga Kapłańska w Septuagincie, Collectanea Theologica 80(2010)4, s. 69-77; t a ż, Księga Rodzaju w Septuagincie, Biblica et Patristica Thoruniensia 4/2011, s. 96-102.

${ }^{100}$ J. M. D i n e s, The Minor Prophets, w: J. K. A i t k e n (red.), The T\&T Clark Companion to the Septuagint, s. 441; W.E. G 1 e n n y, Hosea. A Commentary Based on Hosea in Codex Vaicanus, s. 18-19. 
Słowa kluczowe: Księga Ozeasza, hermeneutyka biblijna, przekłady biblijne, techniki przekładu, Septuaginta

Keywords: The Book of Hosea, biblical heremeutics, biblical translations, translation techniques, the Septuagint

\section{The Book of Hosea in the Septuagint}

Summary

The Book of Hosea plays a special role in the life and theology of ancient Israel. Serving as an opening to the Minor Prophets (the Book of the Twelve) both in the Hebrew and Greek traditions, it is a source of important theological interpretations. The article focuses on the Book of Hosea in the Septuagint. It presents its role in the context of the Greek Book of the Twelve, together with the manuscripts and critical editions of LXXHos, indicating the textual richness of this book in antiquity. It also attempts to show the character of the Greek text, its translation techniques, its omissions and additions and other aspects, discussing also the dating of the book in the Greek tradition. 